\title{
Pneumococcal pneumonia coinfection in critically ill patients with influenza a (h1n1) primary viral pneumonia
}

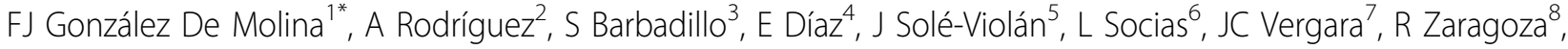 \\ B Suberviola ${ }^{9}$, L Vidaur ${ }^{10}$, R Ferrer ${ }^{11}$, I Martín-Loeches ${ }^{12}$, SEMICYUC/GETGAG Working Group
}

From ESICM LIVES 2015

Berlin, Germany. 3-7 October 2015

\section{Introduction}

It has been generally believed that influenza virus infection increase susceptibility to invasive pneumococcal pneumonia. However, information regarding the impact of S. pneumoniae respiratory coinfection $(\mathrm{SpCoI})$ in patients affected with $\mathrm{A}(\mathrm{H} 1 \mathrm{~N} 1)$ primary viral pneumonia is scarce.

\section{Objectives}

Our aim was to analyse the demographic and clinical differences between patients admitted to ICU due to A (H1N1) pneumonia with and without SpCoI.

\section{Methods}

Prospective, observational, multicenter study conducted in 148 Spanish ICUs. Individuals with A(H1N1) confirmed using RT-PCR during the 2009 to 2014 influenza seasons were included and compared with those patients with SpCoI. Patients' demographic, clinical, radiologic features, laboratory values, ICU and hospital length of stay (LOS) and outcomes were recorded. Discrete variables are expressed as counts (percentage) and continuous variables as medians with 25 th to 75 th interquartile range (IQR). Differences between groups were assessed using the $\mathrm{x} 2$ test and the Fisher exact test for categoric variables and Mann-Whitney U test for continuous variables.

\section{Results}

Of 2343 patients with confirmed A(H1N1) pneumonia, 208 were excluded due to respiratory coinfection by nonpneumococal microorganism. At all, 1949 patients with $\mathrm{A}(\mathrm{H} 1 \mathrm{~N} 1)$ pneumonia were compared to 186 patients

${ }^{1}$ Mutua Terrassa University Hospital, Terrassa, Spain

Full list of author information is available at the end of the article with documented SpCoI (incidence=8.7\%). Patients SpCoI presented a higher APACHE II score (14 [10-19] vs 17 [12-21.5], $\mathrm{P}=0.001)$ and SOFA score (5 [3-8] vs 6 [4-9], $\mathrm{P}=0.002)$. Patient with SpCoI were less obese (36.8\% vs $22.2 \%, \mathrm{P}<0.001)$. HIV presented $\mathrm{SpCoI}$ more frequently ( $2.0 \%$ vs $4.3 \%, \mathrm{P}=0.036)$. No other differences in comorbidities were observed. Patients who had coinfection developed acute kidney injury more frequently (22.8\% vs $32.4 \%, \mathrm{P}=0.004)$ but no difference in renal replacement therapy was observed $(10.8 \%$ vs $11.5 \%, \mathrm{P}=$ $0.773)$. Shock requiring vasopressors were more frequently in those patients with $\mathrm{SpCoI}(49.7 \%$ vs $61.1 \%$, $\mathrm{P}=0.003)$. No differences were observed in invasive mechanical ventilation $(68.8 \%$ vs $65.0 \%, \mathrm{P}=0.211)$, prone positioning ( $18 \%$ vs $15.1 \%, \mathrm{P}=0.331)$ or LOS. Coinfection was not associated with increased ICU mortality $(19.5 \%$ v $21.0 \%, \mathrm{P}=0.627)$.

\section{Conclusions}

Incidence of SpCoI among Influenza virus infection admitted to ICU was low. There was no difference in LOS or mortality for patients with SpCoI despite their greater severity and organ dysfunction at ICU admission.

\footnotetext{
Authors' details

${ }^{1}$ Mutua Terrassa University Hospital, Terrassa, Spain. ${ }^{2}$ Hospital Universitari de Tarragona Joan XXIII, Tarragona, Spain. ${ }^{3}$ Hospital General de Cataluña, Sant Cugat del Valles, Spain. ${ }^{4}$ ParcTaulí Hospital, Sabadell, Spain. ${ }^{5}$ Hospital Dr. Negrín, Las Palmas de Gran Canaria, Spain. ${ }^{6}$ Hospital Son Llatzer, Mallorca, Spain. ${ }^{7}$ Hospital de Cruces, Vizcaya, Spain. ${ }^{8}$ Hospital Dr. Peset, Valencia, Spain. ${ }^{9}$ Hospital Universitario de Santander, Santander, Spain. ${ }^{10}$ Hospital de Donostia, San Sebastián, Spain. ${ }^{11}$ Mútua Terrassa University Hospital, Intensive Care, Terrassa, Spain. ${ }^{12}$ St James's University Hospital, Dublin, Ireland.
}

Published: 1 October 2015

\section{SpringerOpen ${ }^{\circ}$}

(c) 2015 González De Molina et al.; This is an Open Access article distributed under the terms of the Creative Commons Attribution License (http://creativecommons.org/licenses/by/4.0), which permits unrestricted use, distribution, and reproduction in any medium, provided the original work is properly cited. 


\section{References}

1. Hament $J M$, Kimpen JL, Fleer A, Wolfs TF: Respiratory viral infection predisposing for bacterial disease: a concise review. FEMS Immunol Med Microbiol 1999, 26:189-95.

2. Martín-Loeches I, Sanchez-Corral A, Diaz E, Granada RM, Zaragoza R, Villavicencio C, Albaya A, Cerdá E, Catalán RM, Luque P, Paredes A, Navarrete I, Rello J, Rodríguez A, H1N1 SEMICYUC Working Group: Community-acquired respiratory co-infection (CARC) in critically ill patients infected with pandemic 2009 influenza A (H1N1) virus infection. Chest 2011, 139:555-562.

doi:10.1186/2197-425X-3-S1-A829

Cite this article as: González De Molina et al:: Pneumococcal pneumonia coinfection in critically ill patients with influenza a $(h 1 n 1)$ primary viral pneumonia. Intensive Care Medicine Experimental 2015 3(Suppl 1):A829.

\section{Submit your manuscript to a SpringerOpen ${ }^{\mathcal{O}}$ journal and benefit from:}

- Convenient online submission

- Rigorous peer review

- Immediate publication on acceptance

- Open access: articles freely available online

- High visibility within the field

- Retaining the copyright to your article

Submit your next manuscript at $\gg$ springeropen.com 